\title{
Water balance of the basin of Mandali/ east part of Iraq
}

\author{
Qusai Y. AL-Kubaisi ${ }^{1}$, Tariq Abed Hussain ${ }^{2}$ \\ ${ }^{1}$ Department of Geology, College of Science, Baghdad University, Baghdad, Iraq \\ ${ }^{2}$ Building and Construction Department, University of Technology, Baghdad, Iraq \\ E-mail:qusaikubs@yahoo.co.uk
}

\section{Abstract}

Mandali Basin is located between latitudes (33 $39^{\prime} 00^{\prime \prime}$ and $33^{\circ}$ $\left.54^{\prime} 55^{\prime \prime}\right)$ to the north and longitudes $\left(45^{\circ} 11^{\prime} 00^{\prime \prime}\right.$ and $\left.45^{\circ} 40^{\prime} 00^{\prime \prime}\right)$ to the east; to the east of Diyala province at the Iraqi-Iranian border; the basin area is approximately $491 \mathrm{~km}^{2}$.

From the study of climate reality of the basin between 19902013and assessment of the basic climate transactions, it was found that the annual rate of rainfall is $253.02 \mathrm{~mm}$, the relative humidity $(44.4 \%)$, the temperature $\left(21.3{ }^{\circ} \mathrm{C}\right)$, wind speed $(2.08 \mathrm{~m} / \mathrm{sec}$.$) ,$ sunshine ( $8.27 \mathrm{~h} /$ day) and evaporation of the basin class (a) (271.98 $\mathrm{mm})$ and corrected potential evapotranspiration $(80.03 \mathrm{~mm})$. The results of the data analysis show that, there are three basic periods of climate variability wet period, semi wet and dry period.

This study shows that, there is water surplus of $60.87 \%$ of the rainfall amount which is equivalent to $154.03 \mathrm{~mm}$, the amount of runoff is $7.47 \mathrm{~mm}$, and the amount of water recharge is $146.56 \mathrm{~mm}$.

\section{Keywords}

Mandali Basin, Water balance, Water surplus.

\section{Article info.}

Received: Jan. 2015

Accepted: Jan. 2015

Published: Apr. 2015

$$
\begin{aligned}
& \text { الموازنة المائية لحوض مندلي/ شرق العراق } \\
& \text { قصي ياسين الكبيسي، طارق عبد حسين2 }
\end{aligned}
$$

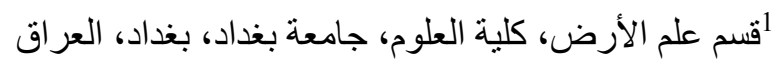

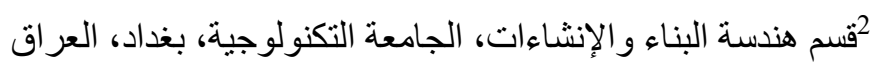

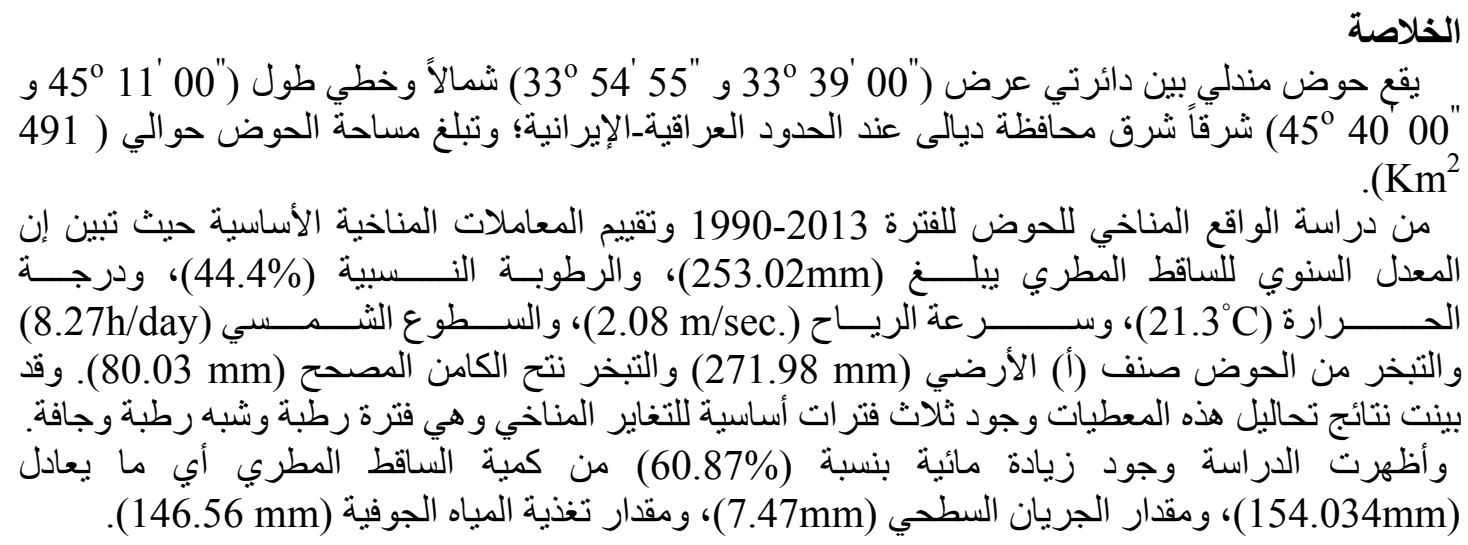

\section{Introduction}

Mandali Basin is located between latitudes ( $33^{\circ} 54^{\prime \prime} 55^{\prime}-33^{\circ} 39^{\prime \prime}$ $\left.00^{\prime}\right)$ to the north and longitudes $\left(45^{\circ}\right.$ $\left.40^{\prime \prime} 00^{\prime}-45^{\circ} 11^{\prime \prime} 00^{\prime}\right)$ to the east; to the east of Diyala province, at the Iraqi-
Iranian border; the basin area is approximately $\left(491 \mathrm{~km}^{2}\right)$. Fig. 1 it can be seen that, the rock exposures in the basin extends from the age (PlioceneRecent) which is represented by Euphrates, Fetha (lower Fars), Anjana 
(upper Fars) and Muqdadiyah and Bai Hassan as well as the deposits of Quaternary [1].

\section{Study area}

Structurally the study area is located within the central eastern part of the Mesopotamian plain and at the southwestern part of the foothill [1]. Region containing some of the geomorphological phenomena of the basin, which is the hills, plains and valleys, as, characterized by the presence of the parallel and dendritic drainage patterns [2]. The area is represented as a good agricultural land where pomegranate orchards and palm are present with cultivation of seasonal crops, wheat and barley. Also famous for herding sheep and cows are a better area in Iraq.
The study of climatic elements in hydrogeological studies is aimed to calculate the water balance of the groundwater. One of the climate factors which affects the calculating is that the amount and intensity of rainfall, the spread of the fallen and the relative humidity, which is considered as one of the water availability elements in the region. While the temperature, sunshine, wind speed and evaporation of the basin class (a) and the potential evapotranspiration basic elements of water loss. Atlas has to take advantage of Iraq's climate and climate information recorded in the stations Badra $(\mathrm{Ba})$ and Khanaqin $(\mathrm{Ka})$ for the period (1990-2013) and through the monthly averages of climate elements account for the Mandali.

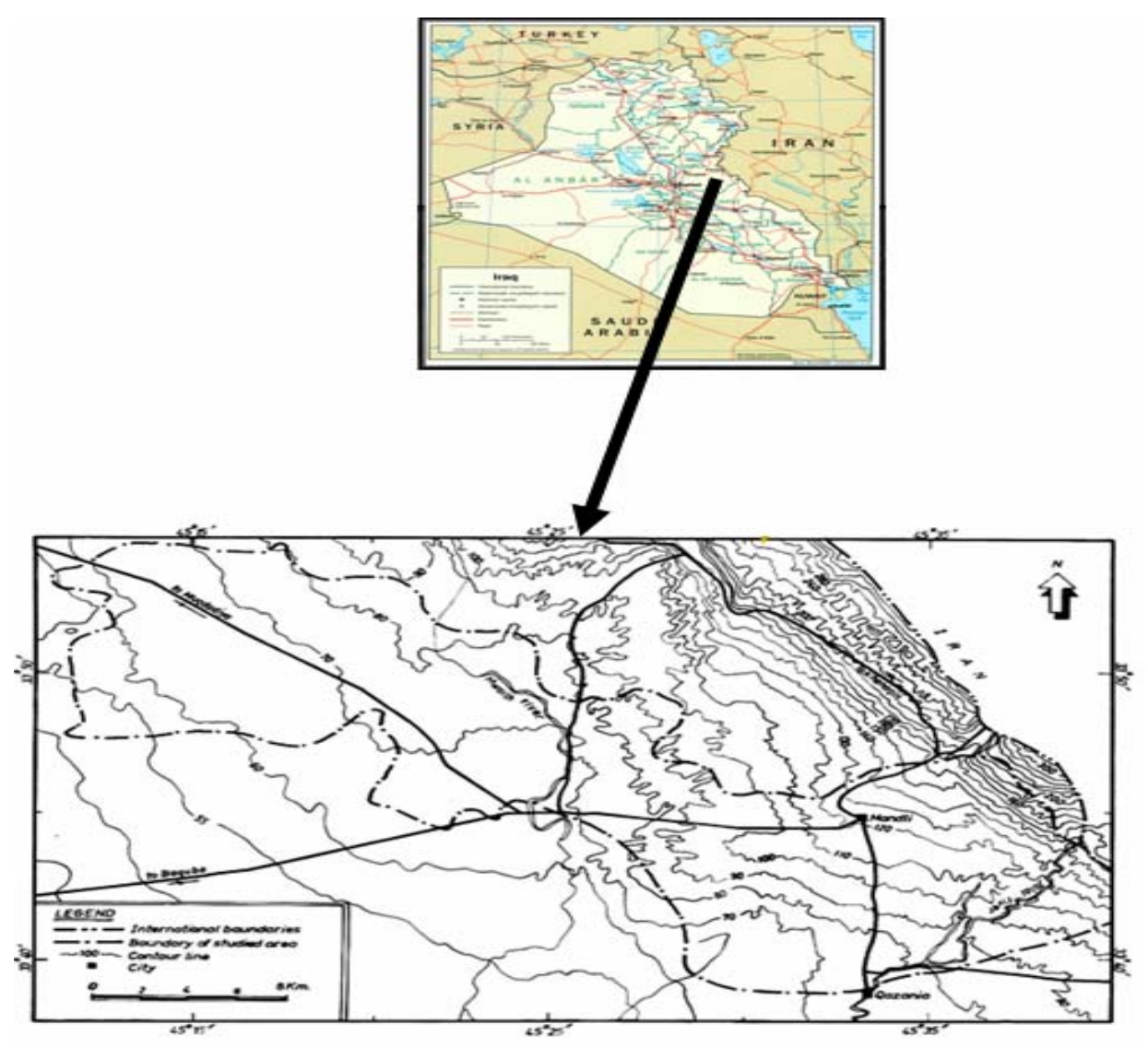

Fig.1: Map of Iraq shows the area of study. 
Table 1: Monthly averages for the various stations of Khanaqin climatic elements (Ka) and Badra (Ba) for the period from (1990 - 2013) [3].

\begin{tabular}{|l|c|c|c|c|c|c|c|c|c|c|c|c|}
\hline Months & \multicolumn{2}{|c|}{ Rainfall(mm) } & \multicolumn{2}{|c|}{ R.H.\% } & \multicolumn{2}{c|}{$\begin{array}{c}\text { Temperature } \\
(\mathbf{C})\end{array}$} & \multicolumn{2}{c|}{$\begin{array}{c}\text { Wind } \\
\text { Speed(m/sec) }\end{array}$} & \multicolumn{2}{|c|}{ S.SH.(h./day) } & \multicolumn{2}{|c|}{$\begin{array}{c}\text { Evaporation } \\
\text { (mm) }\end{array}$} \\
\hline & $\mathrm{Ka}$ & $\mathrm{Ba}$ & $\mathrm{Ka}$ & $\mathrm{Ba}$ & $\mathrm{Ka}$ & $\mathrm{Ba}$ & $\mathrm{Ka}$ & $\mathrm{Ba}$ & $\mathrm{Ka}$ & $\mathrm{Ba}$ & $\mathrm{Ka}$ & $\mathrm{Ba}$ \\
\hline Oct. & 17.2 & 16.11 & 39.94 & 34.2 & 25.2 & 26.7 & 1.18 & 2.37 & 7.5 & 8.5 & 276.45 & 233.38 \\
\hline Nov. & 64.8 & 36.05 & 60.9 & 56.4 & 16.9 & 18.41 & 0.94 & 2.01 & 6.66 & 7.08 & 127.98 & 111.95 \\
\hline Dec. & 51.86 & 32.25 & 71.1 & 67.05 & 11.8 & 12.81 & 0.87 & 2.15 & 5.36 & 6.0 & 75.7 & 70.85 \\
\hline Jan. & 62.35 & 41.65 & 76.7 & 71.27 & 10.54 & 11.47 & 1.105 & 2.42 & 5.5 & 6.0 & 58.78 & 65.44 \\
\hline Feb. & 29.0 & 24.5 & 68.94 & 59.94 & 11.6 & 13.15 & 1.279 & 2.71 & 6.04 & 7.0 & 109.36 & 97.55 \\
\hline Mar. & 42.7 & 23.9 & 58.7 & 46.9 & 14.9 & 16.8 & 1.39 & 3.18 & 6.78 & 7.87 & 190.9 & 184.27 \\
\hline Apr. & 28.24 & 14.32 & 49.9 & 40.1 & 21.4 & 23.46 & 1.53 & 3.27 & 7.25 & 8.2 & 246.9 & 243.8 \\
\hline May. & 6.3 & 12.27 & 35.36 & 29.0 & 29.3 & 30.9 & 1.41 & 3.0 & 8.7 & 9.35 & 335.56 & 349.25 \\
\hline Jun. & 0.0 & 0.46 & 27.2 & 21.68 & 33.8 & 34.92 & 1.33 & 3.88 & 10.32 & 11.9 & 472.63 & 459.4 \\
\hline Jul. & 0.0 & 0.0 & 25.9 & 20.3 & 36.2 & 37.2 & 1.35 & 3.86 & 10.2 & 11.46 & 556.13 & 496.93 \\
\hline Aug. & 0.0 & 0.0 & 26.57 & 20.95 & 34.9 & 36.3 & 1.26 & 3.47 & 10.05 & 11.5 & 540.4 & 463.15 \\
\hline Sep. & 0.09 & 1.93 & 31.0 & 25.35 & 30.8 & 31.96 & 1.13 & 2.95 & 9.2 & 10.4 & 409.42 & 351.6 \\
\hline
\end{tabular}

Due to the occurrence of Mandali basin between stations Badra climate and Khanaqin, the arithmetic mean is used to extract the monthly values of different climatic elements of the proposed station Mandali Table 2.

Table 2: The monthly averages of rainfall, relative humidity, temperature, wind speed and sun shine and evaporation basin class (a) for the period (1990-2013), calculated for the station Mandali (Ma) proposed.

\begin{tabular}{|c|c|c|c|c|c|c|}
\hline Months & $\begin{array}{c}\text { Rainfall } \\
(\mathbf{m m})\end{array}$ & $\mathbf{R . H . \%}$ & $\begin{array}{c}\text { Temperature } \\
(\mathbf{C})\end{array}$ & $\begin{array}{c}\text { Wind Speed } \\
(\mathbf{m} / \mathbf{s e c})\end{array}$ & $\begin{array}{c}\text { S.Sh.(h./day) } \\
\text { Evaporation } \\
(\mathbf{m m})\end{array}$ \\
\hline Oct. & 16.65 & 37.07 & 25.95 & 1.77 & 8.0 & 254.9 \\
\hline Nov. & 50.4 & 58.65 & 17.65 & 1.47 & 6.87 & 119.96 \\
\hline Dec. & 42.1 & 69.07 & 12.3 & 1.51 & 5.68 & 73.27 \\
\hline Jan. & 52.0 & 73.98 & 11.0 & 1.76 & 5.75 & 62.11 \\
\hline Feb. & 26.75 & 64.44 & 12.37 & 2.0 & 6.52 & 103.45 \\
\hline Mar. & 33.3 & 52.8 & 15.85 & 2.28 & 7.3 & 187.6 \\
\hline Apr. & 21.28 & 45.0 & 22.43 & 2.4 & 7.7 & 245.35 \\
\hline May. & 9.3 & 32.3 & 30.1 & 2.2 & 9.0 & 342.4 \\
\hline Jun. & 0.23 & 24.44 & 34.36 & 2.6 & 11.11 & 466.0 \\
\hline Jul. & 0.0 & 23.1 & 36.7 & 2.6 & 10.83 & 526.53 \\
\hline Aug. & 0.0 & 23.76 & 35.6 & 2.36 & 10.77 & 501.77 \\
\hline Sep. & 1.01 & 28.17 & 31.4 & 2.04 & 9.8 & 380.51 \\
\hline Total & 253.02 & & & & & \\
\hline $\begin{array}{c}\text { Monthly } \\
\text { Mean }\end{array}$ & & 44.4 & 21.3 & 2.08 & 8.27 & 271.98 \\
\hline
\end{tabular}




\section{Potential evapotranspiration}

Thornthwiate suggested an equation to calculate the potential evapotranspiration after conducting several experiments on various semi- wet and semi-arid climate types depending on the temperature only [4] Thornthwiate's equation is applied to calculate the monthly potential evapotranspiration as shown in Table3.

Table 3: Potential evapotranspiration (PE) $\mathrm{mm}$ for Mandali Basin by Thornthwiate.

\begin{tabular}{|c|c|c|c|c|c|c|c|c|}
\hline Months & $\begin{array}{c}\mathbf{a}=\mathbf{2 . 6 6 2} \\
\mathbf{t}^{\circ} \mathbf{C}\end{array}$ & $\mathbf{t} / \mathbf{5}$ & $\mathbf{J =}(\mathbf{t} / \mathbf{5})^{\mathbf{1 . 5 1 4}}$ & $\mathbf{1 0 t} / \mathbf{J}$ & $\mathbf{( 1 0 t / J}^{\mathbf{a}}$ & $\begin{array}{c}\mathbf{P E} \\
(\mathbf{m m})\end{array}$ & $\mathbf{D T} / \mathbf{3 6 0}$ & $\begin{array}{c}\mathbf{P E}_{\mathbf{c}} \\
(\mathbf{m m})\end{array}$ \\
\hline Oct. & 25.95 & 5.19 & 12.1 & 1.919 & 5.669 & 90.704 & 0.68 & 61.67 \\
\hline Nov. & 17.65 & 3.53 & 6.75 & 1.305 & 2.031 & 32.496 & 0.57 & 18.24 \\
\hline Dec. & 12.3 & 2.46 & 3.907 & 0.91 & 0.778 & 12.448 & 0.49 & 6.1 \\
\hline Jan. & 11.0 & 2.2 & 3.299 & 0.813 & 0.576 & 9.216 & 0.5 & 4.61 \\
\hline Feb. & 12.37 & 2.47 & 3.931 & 0.915 & 0.789 & 12.624 & 0.51 & 6.438 \\
\hline Mar. & 15.85 & 3.17 & 5.736 & 1.172 & 1.525 & 24.4 & 0.62 & 15.128 \\
\hline Apr. & 22.43 & 4.48 & 9.683 & 1.659 & 3.847 & 61.552 & 0.64 & 38.16 \\
\hline May. & 30.1 & 6.02 & 15.146 & 2.226 & 8.416 & 134.656 & 0.77 & 103.68 \\
\hline Jun. & 34.36 & 6.87 & 18.499 & 2.542 & 11.983 & 191.728 & 0.92 & 176.39 \\
\hline Jul. & 36.7 & 7.34 & 20.448 & 2.715 & 14.278 & 228.448 & 0.93 & 212.45 \\
\hline Aug. & 35.6 & 7.12 & 19.527 & 2.633 & 13.159 & 210.544 & 0.92 & 193.7 \\
\hline Sep. & 31.4 & 6.28 & 16.147 & 2.323 & 9.428 & 150.848 & 0.82 & 123.69 \\
\hline Total & & & 135.173 & & & 1317.69 & & 960.256 \\
\hline
\end{tabular}

where:

PE: Monthly potential evapotranspiration $(\mathrm{mm}), \quad \mathrm{PE}_{\mathrm{C}}$ : corrected potential evapotranspiration $(\mathrm{mm})$, D: number of day in the month, $\mathrm{T}$ : number of possible sun shine (hours).

\section{Water surplus (WS) and water deficit (WD)}

Water surplus is defined as the excess of rainfall over the corrected potential evapotranspiration values during specific months of the year, while water deficit is the excess of corrected potential evapotranspiration values over rainfall during the remaining months of that year. According to [5], the actual evapotranspiration APE can be derived as follows:

$$
\begin{array}{cc}
\mathrm{APE}=\mathrm{PEc} & \text { when } \mathrm{P} \geq \mathrm{PEc} \\
\mathrm{APE}=\mathrm{P} & \text { when } \mathrm{P}<\mathrm{PEc}
\end{array}
$$

In the first case (water surplus period) the value of rainfall is greater than PEc, and the APE is equal to the
PEc value; while in the second case (water deficit period) PEc is greater than rainfall; the APE is equal to rainfall values as expressed in the following:

$\mathrm{WS}=\mathrm{P}-\mathrm{PEc}$

$\mathrm{P}>\mathrm{PEc}, \mathrm{PEc}=\mathrm{APE}$

$\mathrm{WD}=\mathrm{PEc}-\mathrm{P}$

$\mathrm{P}<$ PEc, $\mathrm{P}=$ APE

where:

WS: Water surplus (mm)

WD: Water deficit (mm), P: Rainfall (mm), PEc: Corrected potential Evapotranspiration factor ( $\mathrm{mm}$ ).

APE: Actual Potential Evapotranspiration factor $(\mathrm{mm})$.

The WS and WD are calculated without using the soil moisture (equal to zero). Table 4 shows the monthly averages of APE, WS and WD; the water surplus period is limited between November and March because rainfall exceeds PEc, while the remaining months represent water deficit period where PEc exceeds the rainfall. 
The WS amount is $(153.034 \mathrm{~mm})$ from total rainfall $(253.02 \mathrm{~mm})$, therefore the water surplus ratio from the annual rainfall can be represented as:

$\mathrm{WS} \%=\mathrm{WS} / \mathrm{P} \times 100$

WS $\%=153.034 / 253.02 \times 100=$ $60.87 \%$

This percentage represents the groundwater recharge and surface runoff. While the amount of WD is $(860.59 \mathrm{~mm})$ from the corrected potential Evapotranspiration (PEc), which equal to $39.13 \%$ from the total rainfall as in the following equation:

$\mathrm{WD} \%=100-\mathrm{WS} \%$

WD $\%=100-60.87 \%=39.13 \%$
Fig. 2 shows the relationship between the monthly average of rainfall and corrected potential evapotranspiration, which shows the water surplus and water deficit periods.

Surface Runoff is an important component of the water balance of the hydrological basins. The annual runoff verified account of the water surplus in the study area by adopting the following mathematical formula [6].

$$
\begin{aligned}
& \mathrm{R}_{\mathrm{s}}=(\mathrm{P}-17.8) \mathrm{P} / 254 \\
& \mathrm{Ws}=\mathrm{R}_{\mathrm{s}}+\mathrm{R}_{\mathrm{e}} \\
& \text { Where: } \\
& \mathrm{P}: \text { Total annual rainfall }(\mathrm{mm}) \\
& \mathrm{R}_{\mathrm{s}} \text { : surface Runoff }(\mathrm{mm}) \\
& \mathrm{R}_{\mathrm{e}} \text { : Groundwater Recharge }(\mathrm{mm})
\end{aligned}
$$

Table 4: Water surplus of the study area for the period (1990-2013).

\begin{tabular}{|c|c|c|c|c|c|}
\hline Months & $\mathbf{P}(\mathbf{m m})$ & $\mathbf{P E}_{\mathbf{c}}(\mathbf{m m})$ & $\mathbf{A E}(\mathbf{m m})$ & $\mathbf{W S}(\mathbf{m m})$ & $\mathbf{W D}(\mathbf{m m})$ \\
\hline Oct. & 16.65 & 61.67 & 16.65 & 0 & 45.02 \\
\hline Nov. & 50.4 & 18.24 & 18.24 & 32.16 & 0 \\
\hline Dec. & 42.1 & 6.1 & 6.1 & 36.0 & 0 \\
\hline Jan. & 52.0 & 4.61 & 4.61 & 47.39 & 0 \\
\hline Feb. & 26.75 & 6.438 & 6.438 & 20.312 & 0 \\
\hline Mar. & 33.3 & 15.128 & 15.128 & 18.172 & 0 \\
\hline Apr. & 21.28 & 38.16 & 21.28 & 0 & 16.88 \\
\hline May. & 9.3 & 103.68 & 9.3 & 0 & 93.7 \\
\hline Jun. & 0.23 & 176.39 & 0.23 & 0 & 176.16 \\
\hline Jul. & 0.0 & 212.45 & 0.0 & 0 & 212.45 \\
\hline Aug. & 0.0 & 193.7 & 0.0 & 0 & 193.7 \\
\hline Sep. & 1.01 & 123.69 & 1.01 & 0 & 122.68 \\
\hline Total & 253.02 & 960.306 & & 154.034 & 860.59 \\
\hline
\end{tabular}

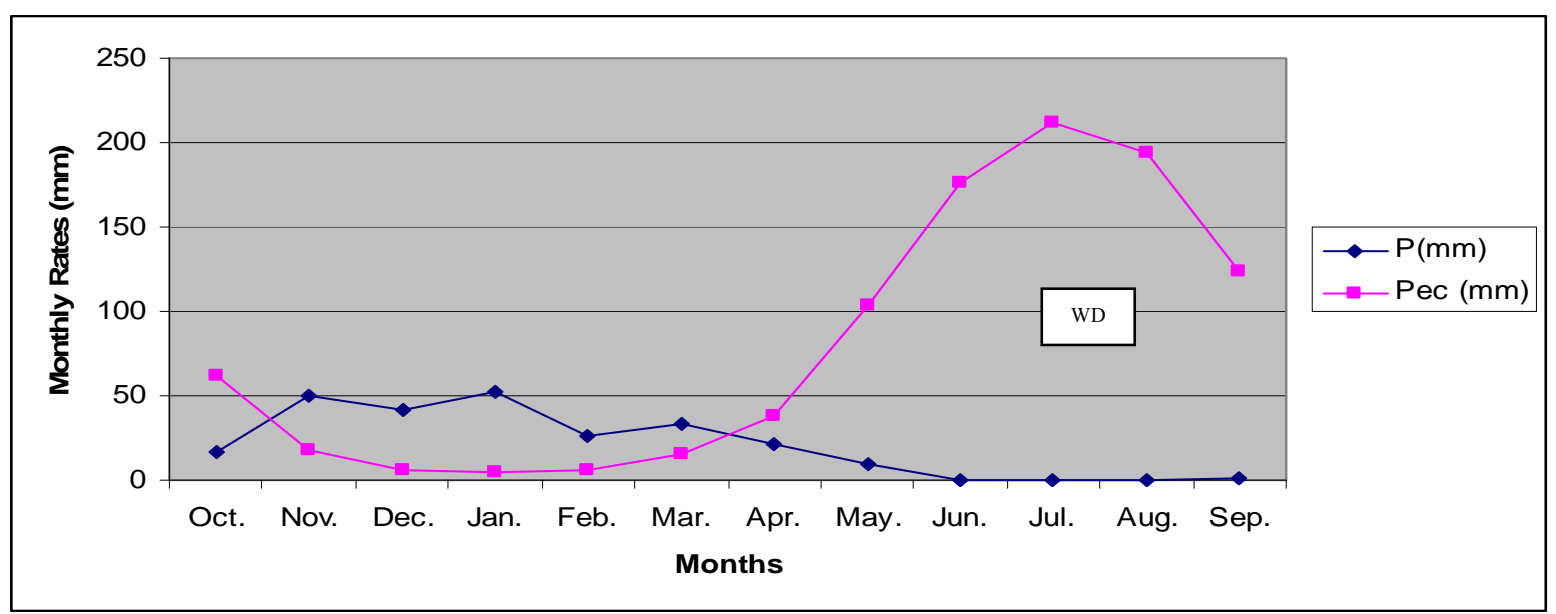

Fig.(2) : The relationship between monthly averages of rainfall (P)and corrected potential evapotranspiration, shows water surplus(WS) and the water deficit (WD)for the study area. 
The limitations of the applied this equation to calculate the runoff basins hydrological is that the total annual rainfall is not less than $178 \mathrm{~mm}$.

The water balance calculations is performed by depending on the rainfall and the potential evapotranspiration rates for the period (1990-2013) set out in the Table 4 where the total annual rainfall was $253.02 \mathrm{~mm}$ with water surplus (154.034) mm, which is constitute a percentage of annual rainfall $(60.87 \%) \mathrm{mm}$. This increase is divided into the surface runoff (Rs) value of (7.47) $\mathrm{mm}$, the rate of annual rainfall $(2.95 \%)$, and the groundwater recharge $(\mathrm{Re})$ value $(146.56 \mathrm{~mm})$ and the rate of annual rainfall $(57.92 \%)$. In general, the rate of water surplus generated from the annual rainfall was
$60.87 \%$ offset $39.13 \%$ water loss through actual evapotranspiration.

\section{Climate classification}

The average of the monthly rainfall values and temperature is used to determine the climate detailed basin Mandali according to the type of classification $[7,8]$ who adopted the Humidity Index (HI), which represents the ratio between the rainfalls $(\mathrm{P})$ to the potential evapotranspiration (PE). According to the application of both classifications, which are mentioned above, the predominant type of climate during the months of the year of the study area as shown in the Table 5.

$$
\text { H.I. }=\mathrm{P} / \mathrm{PE}
$$

Table 5: Evaluation of monthly climate averages in the study area according to the (Brown and Cocheme, 1973) [8] and (Kettanha and Gangophhyaya, 1974) [7].

\begin{tabular}{|c|c|c|c|c|c|}
\hline Month & $\mathbf{P}(\mathbf{m m})$ & $\mathbf{P E}(\mathbf{m m})$ & H.I. & $\begin{array}{c}\text { Kettanha and } \\
\text { Gangophhyaya,1974 [8] }\end{array}$ & $\begin{array}{c}\text { Brown and } \\
\text { Cocheme, 1973 [7] }\end{array}$ \\
\hline Oct. & 16.65 & 90.704 & 0.183 & Moderate to Dry & Dry \\
\hline Nov. & 50.4 & 32.496 & 1.55 & Humid & Humid \\
\hline Dec. & 42.1 & 12.448 & 3.38 & Humid & Humid \\
\hline Jan. & 52.0 & 9.216 & 5.64 & Humid & Humid \\
\hline Feb. & 26.75 & 12.624 & 2.12 & Humid & Humid \\
\hline Mar. & 33.3 & 24.4 & 1.36 & Humid & Humid \\
\hline Apr. & 21.28 & 61.552 & 0.345 & Moist & Moist \\
\hline May. & 9.3 & 134.656 & 0.07 & Dry & Very Dry \\
\hline Jun. & 0.23 & 191.728 & 0 & Dry & Very Dry \\
\hline Jul. & 0.0 & 228.448 & 0 & Dry & Very Dry \\
\hline Aug. & 0.0 & 210.544 & 0 & Dry & Very Dry \\
\hline Sep. & 1.01 & 150.848 & 0 & Dry & \\
\hline
\end{tabular}

The climate class is identifying by using the annual dry coefficient, which is suggested by Al-Kubaisi [9]. This classification, which depends on the rainfall and temperature, shows that the climate of the study area is a Sub arid.

\section{Conclusions}

1. The different climatic transactions account for the proposedstation
Mandali of climate information obtained through the stations of Khanaqin and Badra period (19902013).

2. This study showed that there is the water balance in the basin by $60.8 \%$ of the amount of rainfall, which is equivalent to $154.034 \mathrm{~mm}$.

3. The water balance is divided into surface runoff $7.47 \mathrm{~mm}$ with a rate of $2.95 \%$ and groundwater recharge of 
$146.56 \mathrm{~mm}$ with a rate of $57.92 \%$ of the annual rainfall. The water deficit represents $860.59 \mathrm{~mm}$ of the corrected potential evapotranspiration.

4. This study showed that the climate of the study area is between the wet climates in winter to the dry climate in summer and in general, it can be considered that the climate of the region is Sub arid.

\section{References}

[1] T.Buday, "The regional Geology of Iraq". Vol.1, Stratigraphy and Paleontology, Kassab I.I.M. and Jassim S.Z., (Editors) Som, Baghdad. 445p. Dar Al-Kutib Pub. House, Univ. of Mosul, Iraq, 1980.

[2] R.M. Parson, "Groundwater resources of Iraq", Vol.4, Mandali area. R.m. Parson Co., Ministry of Development, Development-Board, Gov. of Iraq, 1956, 118P.

[3] Iraqi Meteorological Organization, "Climatic elements data of recorded in Khanaqin and Badra stations for period from (1990-2013)", 2014.
[4] C.W. Thornthwiate, Geographical Review, 38, (1948) 55-94.

[5] N. D.Lerner, A. S.Issar, Simmers, I., "Groundwater Recharge, A Guide to Understanding and Estimating Natural Recharge", Vol.8, Association of Hydrogeologist, Hanover, 1990.

[6] M.M.Dandekar, K.N. Sharma: "Water power Engineering", Vicas Publishing House Pvt. Ltd. NewDelhe, 1989, 451P.

[7]M.S.Kettaneh, Gangopadhyaya, M., "Climatologic water budget and water availability periods of Iraq", IARNR, Baghdad, Tech. No. 65, (1974) 19p.

[8] L. H.Brown, Cocheme J, W.M.O. Geneva, 125(1973) 197.

[9] Q.Y.Al-Kubaisi, Iraq, Jour. Sci., 45c, 1 (2004) 32-40. 